\title{
FOOD SERVICES IN HOTELS OF THE CITY OF JOÃO PESSOA/PB FROM THE PERSPECTIVE OF THE MANAGERS OF A\&B
}

\author{
Robson do Vale Silva ${ }^{a}$ \\ Adriana Brambillab \\ Marcleide Maria Macêdo Pederneiras ${ }^{c}$ \\ Elídio Vanzellad
}

\begin{abstract}
This study analyzes the importance of food services in hotels in the city of João Pessoa - Paraíba, from the perspective of A\&B managers. For this purpose, five hotel developments located in the city of João Pessoa were analyzed. This was characterized as a qualitative study with an exploratory stage. Field data were collected through interviews based on a semi-structured script, conducted between December 11, 2019 and March 6, 2020 with five hotels listed in the Register of Tourist Service Providers of the Ministry of Tourism (CADASTUR). It was found that all the hotels have their own management, and that the managers of the hotels surveyed consider food services to be market differentials for attracting different types of publics through the promotion of regional culture in the dishes served, and that this was important to attract customers, local residents and guests from other hotels.
\end{abstract}

\section{Keywords:}

Hotel

Restaurants

Management 


\section{INTRODUCTION}

Based on the premise that hotels offer services other than accommodation, food has become increasingly important in this sector, representing revenue and profitability for companies in this market. Hence, there are some key factors to consider when seeking to focus specifically on food in hotels, and from these, the planning of a service that is suited to the needs of the clientele - important agents for stimulating the growth of these establishments (Silva, 2006, p.17).

In a competitive environment, the guest tends to seek increasingly distinct and customized services, Thus, the offer of food services can be a considerable a competitive differential. Bearing in mind that today's consumers are more aware of their rights, the higher the quality of the service offered, the more likely the customer will be to return, bringing better financial returns for the business. For this reason, accommodation establishments must offer not only comfortable accommodation, but also food and beverages $(A \& B)$ that meet the guests' needs, and a good infrastructure that offers benefits for which the guest is willing to pay.

Food services, in general, have become increasingly important for the local economies of cities, as they generate jobs and income, increasing the spending of those employed in this sector. Considering these aspects, it is emphasized that the food services offered in hotels are a way of understanding the relationship that is established between the hotel and the guest.

This study is justified by the importance of publishing academic papers related to food services in accommodation establishments, in this case, in the city of João Pessoa. According to Silva (2006, p.17) the lack of published works on the quality of food services in hotels can have a negative impact on the quality of these services and the development of these activities. This research is also important because it can contribute to the dissemination of knowledge on the subject among hotel professionals, particularly managers of food and beverage sectors, and students in the areas of hospitality and tourism. The contribution of this research can also be extended to the academic theoretical field, and to managers, teachers, students, employees and society in general - indeed, to anyone who is directly or indirectly involved in tourist activities in the region.

This research aims to analyze the importance of food services in the hotels of João Pessoa, in the Brazilian state of Paraíba (PB). It investigates whether the food services provided in the hotels of this seaside capital can, indeed, be considered market differentials, according to managers of the $A \& B$ sector.

\section{TOURISM IN TODAY'S SOCIETY}

Travel from a place of origin to another destination is part of the history of mankind. People travel in search of culture, leisure, to visit relatives, or for religious reasons, among others. Rejowski (2005) explains that the history of travel is intermingled with the history of humanity itself, as moving from one place to another has always been an intrinsic part of human development. However, it was only in the second phase of the Industrial Revolution that tourism began to form and gather strength as a social-economic activity. The Englishman, Thomas Cook was largely responsible for this new configuration of tourism, when in 1841, he chartered a train carriage and conducted the world's first organized tour (Cacho \& Azevedo, 2010). However, the concepts of this activity are much more recent than its practice, and have been the object of study of several areas of contemporary knowledge.

There is no single definition of what tourism is, but the World Tourism Organization (OMT, 2001) defines it as "activities of persons traveling to and staying in places outside their usual environment for not more than one consecutive year for leisure, business and other purposed", which differs from the same-day-visitor, or excursionist who, although he/she visits the same place, does not stay overnight (Wto, 2001).

According Lickorish \& Jenkins (2000), one aspect of the economic concept of tourism is the fact that the traveler spends money at the destination visited. Hence, tourism represents an external application of wealth and significant revenues for the area that receives the tourist. This meaning brings in the economic aspect of tourism, as an activity that boosts the economy of the locality where it is developed, considering that the tourist, regardless of the reason for traveling, spends money at the location. In this respect, "tourism functions as an economic "driver", bringing together basic principles of genuineness, tradition, culture and new strategies for the management and organization of the sector" (Ramos \& Costa, 2017, p, 32).

Tourism is a symbol of the modern consumer society, which is a combination of complementary goods and services. Andrade (1995, p.38) corroborates this statement by stating that "tourism is the complex of activities and services related to travel, transportation, accommodation, food, circulation of typical products, activities related to cultural movements, visits, leisure, and entertainment". All the definitions state that for tourism to exist, people must move around, and use means of transportation, accommodation and food, among other services. 


\section{TOURISM AND FOOD}

In the competitive environment of the food sector, finding out the needs and desires of certain groups it is essential to create planning strategies aimed at the target public. for Kotler (1998), every consumer, seeks, in the purchase of a product or service, to fill a gap, and therefore, to satisfy a need. In relation to physiological needs, Costa (2010, p.38) points out that "these are the most pressing and dominate the direction of behavior if they are not satisfied." At this point, the importance of hunger and its form of suppression (feeding) is highlighted, emphasizing that food is much more than a physiological need. Finkelstein (2005, p.69) states that commensality, "as well as the satisfaction of any appetite, has long ceased to have nutrition as its main objective and, instead, has come to contain countless social, cultural and symbolic meanings."

Mees (2019, p. 166) states that the action of feeding and eating together, "reveals structures of daily life of a given society. It is part of a symbolic system of social codes, which operates in the establishment of relations among those who eat, between them and the society where they live, and between them and nature." The author also identifies that nowadays, the "invention" of an establishment that offers meals from a menu marks a shift from the private dimension of food and commensality, becoming, from the nineteenth century, an important urban infrastructure linked to tourism practices" (Mees, 2019, p. 16, translation ours).

Since tourism and gastronomy are considered hedonistic products, they have an impact on the behavior of several types of tourists (Mak, Lumbers \& Eves, 2011), one of the main tourists' leisure activities is eating out at restaurants. Food is the second highest expense in the travelers' budget (Hall \& Sharples, 2003) and according to Boyne, Williams \& Hall (2002) tourists spend almost $40 \%$ and for Meler \& Cerovic (2003) a third of their budget in food and hotel activities.

Therefore, gastronomy represents an opportunity to revitalize and diversity tourism, boosting the local economy, engaging different protagonists of this sector (producers, cooks, markets, among others), and bringing new purposes to the primary sector. The important role of gastronomy in the choice of destination and tourist consumption has led to an increase in offers based on high quality products, and the consolidation of gastronomic tourism market (WTO, 2012).

\section{FOOD SERVICES IN THE HOTEL IN- DUSTRY}

According to Chon \& Sparrowe (2003 p. 85), "accommodation establishments are not all known by the same name. Over time, guest houses, hotels, motels, and resorts, among others, have offered accommodation to people, but not all of them offer the same services." (Chon \& Sparrowe, 2003, p. 85, translation ours).

The most well-known type of accommodation is hotels, which are almost ubiquitous. The main goal of this type of business is to offer accommodation, regardless of its size, location or other services offered. Torre (2001, p.29) defines a hotel as: "an institution of a public nature that offers accommodation, food and drinks, as well as entertainment, to the traveler and that operates for the purpose of making a profit."

Some of these hotels offer other services besides rooms, such as events center, leisure areas, national or international restaurants, and so on. Among these, food services are the most common due to the demand from both guests and those coming from outside, such as tourists staying at other hotels, visitors and residents of the locality where the hotel is located.

The food service is a notable practice in the history of mankind, as travel and the growth of cities served as strong incentives for the development commercial establishments offering $A \& B$ (Chon \& Sparrowe, 2003).

The hospitality sector must meet the needs and expectations of consumers, which includes food services. However, not all consumers have similar needs and expectations when it comes to these services. Added to that, each consumer may have different interests at different times and in different situations, and there may be room for multiple options, from enjoying a meal in an elegant and expensive restaurant to times when fast food is more practical and expedient. There are also those who are interested in becoming acquainted with the traditional or typical gastronomy of a locality or region.

After accommodation, the second activity provided by hotels is $A \& B$ services. According to Castelli (2006), the $A \& B$ sector is the most complex within the organizational and functional structure of the hotel development, covering spaces as restaurant, kitchen, kitchen pantry, bar and banquets, depending on the size of establishment and the services offered to guests/customers.

The $A \& B$ services of a hotel tend to be spaces where guests can socialize, work and, at the same time, eat or drink. The fact is that no matter the situation, place or reason, food is essential for the human being. However, the ways in which food and drink are prepared and served can represent an important attraction and cultural expression, prompting tourists and travelers to seek them out.

Understanding the food service as part of the tourist offer, it is possible to analyze its importance not only 
as a service, but in some cases, as a tourist attraction, providing traditional dishes that introduce the tourists to local cultures. According to Schlüter (2003, p. 11), "traditional cuisine is increasingly being recognized as a valuable component of peoples' intangible heritage." In this regard, Richards (1999) states that regionalization can be used as a communication and marketing tool for gastronomic tourism, emphasizing that:

if gastronomy can be linked to a specific country or region, it will become a powerful marketing tool. Authenticity has always been seen as an important aspect of tourist consumption, and for those looking for local and regional authenticity, food may become a reason to visit a particular destination (Richards, 1999, p.12).

Adding to this statement, Schlüter (2003) takes the view that the gastronomy of a population or place constitutes a form of expression in which the products and raw materials developed in the environment where this society is formed are used and appreciated.

\section{FOOd \& BeVERAGES SECTOR IN HO-}

\section{TELS}

One of the main goals of every organization or company is to earn revenue. Depending on the characteristics of the products and services offered, this can be done in several ways. Vasconcellos \& Carvalho (2006, p.119) comment on the sources of revenue in a hotel company: "in the tourism sector, the total revenue from sales of, for example, a hotel company is composed of a series of sub-items, such as lodging, food and beverages, ancillary services, and so on."

Addressing the scope of the hotel A\&B sector, Haynes \& Ninemeier (2005, p.204) state that:

in addition, a competent F\&B department usually offers various forms of operation, such as restaurants, 24 -hour room service, banquet operations and numerous other food and beverage alternatives, including fastfood bars, coffee breaks and meal service at conventions/meetings, travel meals and out-of-hotel catering services, vending machines and sales of alcoholic drinks in the lounges. (Haynes \& Ninemeier, 2005, p.204, translation ours).

In large hotels, the $A \& B$ manager is responsible for all the food sectors (Cândido \& Vieira, 2003). But in small and medium-sized establishments, some executive chefs are turning into kitchen managers, adding the management of this department to their functions. This trend for right sizing is also applied to other sectors, as a way of cutting costs and restructuring, aiming to keep only employees considered essential within the company (Walker, 2002)
Many hotels also apply marketing strategies to offer their facilities for banquets, enabling an increase in $A \& B$ and accommodation sales. Others also operate catering services for events outside their facilities, aiming to maximize the use of their kitchen and staff (Chon \& Sparrowe, 2003). This is a service that provides meals and beverages for festive, official or professional occasions (Porto Editora, 2015).

According to Vargas (Vargas, 2009, p.36), the A\&B sector of a hotel produces food "para atender aos hóspedes e visitantes no café da manhã, almoço, jantar e room service (serviço de quarto), administrando os serviços de bar e restaurante do hotel. Além disso, também planeja serviços relacionados aos eventos (banquetes)".

In the context of total revenue, the A\&B sector is important because it represents at least $25 \%$ of the total revenue of a hotel and helps that attract events that generally end up attracting guests to the hotel (Sena, 2008). Walker (2002) explains that about $20 \%$ of a hotel's operating profit is generated by the $A \& B$ department, However, a margin of around $25 \%$ to $30 \%$ is generally considered acceptable, this figure varying depending on the type of establishment.

Haynes \& Ninemeier (2005, p.205) address the importance of $A \& B$ in hotels, stating that "A\&B products are equally indispensable, regardless of their contribution to profitability". For the authors, this statement is due to the fact that "some guests choose a hotel, in part, because of the quality and value of the $A \& B$ services offered".

Some chains and independent hotels choose to outsource $A \& B$ services, aiming at aspects such as cost reduction, increased productivity, and quality improvements, among others. Giosa (1997) considers that outsourcing occurs when activities that are not part of the company's main business are transferred to third parties. The author adds that "outsourcing has a clear focus on quality and cost reduction, generating more results, supporting effectiveness with management optimization" (1997, p. 12).

Akl $(2006, p .16)$ corroborates this statement by mentioning some advantages that outsourcing process brings, such as "economic development, the search for quality of the activity/service provided, improvements of the workforce and in the costing system, greater profitability and obviously, the reduction of costs".

When the sector $A \& B$ is well managed, other benefits that can be achieved are customer loyalty and increased revenue for the hotel. Haynes and Ninemeier (2005, p. 206) discuss this subject, stating that "when the $A \& B$ department is well managed, guests will return. The guest loyalty generated by a competently managed $A \& B$ department is critical to the hotel's success."

Therefore, the A\&B sector, in all its complexity, demands adequate administration in order to serve as an 
efficient source of revenue for the accommodation establishments that choose to manage these types of services.

\section{Methodology}

To achieve the proposed objective, a bibliographic study was carried out, looking for theoretical conceptions related to tourism, hospitality and food services, in order to relate them to the practice observed during the field research. The bibliographic research involved searching electronic and printed theoretical references, such as books, scientific articles and website pages. Any scientific work begins with bibliographical research, as this enables the research to find out what aspects of a given subject have already been studied (Fonseca, 2002).

The research methods used to structure this work is characterized as quantitative and qualitative, as it sought to measure and quantify the answers, in addition to knowing and interpreting the interviewees' opinions

The exploratory nature of the research aims to familiarize the researcher with the issue, in order to make it more explicit. Most of these studies involve bibliographic surveys; interviews with people who had practical experiences with the issue researched, and analysis of examples that stimulate understanding (Gil, 2007).

As a data collection technique, interviews were used to obtain information about the theme studied. According to Gil (2008, p. 109), "the interview is one of the most used data collection techniques in the social sciences", and this is defined "as the technique in which the researcher presents himself before the investigated subject and asks him questions, with the objective of obtaining the data that are of interest to the investigation."

To assist in obtaining the data, a semi-structured interview script was used, which was formulated in advance, with questions about the objective of the work, which was applied to the hotels' A\&B managers. According to Gil (2008, p. 121) the script is defined as a "research technique composed of a set of questions that are submitted to people for the purpose of obtaining information." The script was constructed based on the theoretical foundation and aimed at responding to the objective proposed in the present work.

The selection of hotels was based on the 2018 Register of Tourist Service Providers of the Ministry of Tourism (CADASTUR). The inclusion criteria were hotels located on the seafront of João Pessoa, as this is the area that concentrates the largest number of hotels and tourists, and the hotels here are part of CADASTUR. Initially, 11 hotels were contact ed, but only 5 were selected for the interviews, as they did not outsource their $A \& B$ services. The interviews were conducted between Decem- ber 11th, 2019 and March 6th, 2020. The interviewees were held with the $A \& B$ managers of the hotels, as these were the people best able to answer questions about the activities related to the sector.

\section{ANALysis AND discussion OF RE- SULTS}

After the data collection, analyses were performed based on the theoretical framework presented, showing the main responses obtained and their connections with the references found in the literature review.

In response to the question of whether the interviewees considered the food service to be a market differential, all the respondents (100\%) said they agreed, and that it is through the meals served in their restaurants that they aim to show this differential. Interviewee $\mathrm{H} 2$ said "yes, the hotel has a market differential and makes use of it through the appreciation of local producers, using organic vegetable products that are grown in the hotel itself, creating and innovating in the preparation of dishes for differentiated clienteles, such as vegans and vegetarians, and catering for important gastronomic events such as VegWeek, Restaurant Week and Brasil Sabor." Thus, it was found the hotels view gastronomy as something that enables them to stand out in the hospitality sector and attract the attention of various publics, through the quality of the food services offered. It was observed, in line with the World Tourism Organization (2012), that the leading role of gastronomy has led to an increase in offers based on highquality products and the consolidation of a gastronomic tourism market.

Another point that was evaluated was whether the hotel offered the three main meals and whether there were other food services offered by the restaurant. All the interviewees $(100 \%)$ stated that they served the three main meals (Breakfast, Lunch and Dinner). In relation to other types of services, $100 \%$ of the interviewees said that they offered room service and a bar at their establishments. Interviewee $\mathrm{H} 2$ said "the restaurant, in addition to serving our guests, it is open to the public for breakfast, lunch and dinner. The hotel also offers 24-hour room service and a special menu in its pool bar, valuing regional products." Thus, it was found that all the interviewees (100\%) used similar means to increase the financial income of their hotels, through the $A \& B$ sector.

The hotels were also asked if they offered catering services, with the result that $75 \%$ of the hotels did so, except for $\mathrm{H} 3$, which responded that activity is not part of the hotel's A\&B activities. As seen earlier, catering is a way for the hotel to maximize the use of the kitchen and the own hotel staff (Chon \& Sparrowe, 2003) and consequently increase its source of revenue. 
Regarding the profit margins of the restaurants, 100\% of the interviewees said that the restaurant is financially important for their hotels. The table below illustrates the profit margin of the restaurants according to the interviewees:

Table 1: Profit margin of the hotels

\begin{tabular}{c|c}
\hline Hotel & Profit margin \\
\hline $\mathrm{H} 1$ & - \\
\hline $\mathrm{H} 2$ & $12 \%$ \\
\hline $\mathrm{H} 3$ & $40 \%$ \\
\hline $\mathrm{H} 4$ & $12-15 \%$ \\
\hline $\mathrm{H} 5$ & $30-32 \%$ \\
\hline
\end{tabular}

Source: Research data (2020).

It is important to highlight that in general, $20 \%$ of a hotel's operating profit is generated by the A\&B department, However, a profit margin of $25 \%$ to $30 \%$ is considered acceptable (Walker, 2002). In this aspect, it is perceived that interviewee $\mathrm{H} 3$ had higher profit margins than what the literature deems acceptable. On the other hand, interviewees $\mathrm{H} 2$ and $\mathrm{H} 4$ had margins well below what can be considered acceptable. Interviewee $\mathrm{H} 5$ had profit margins that the author considers to be feasible.

Next, the interviewees were asked if the companies believed the restaurant services offered in the hotels of João Pessoa city are an effective market differential, and if they considered that they contribute financially. All the hotel representatives interviewed (100\%) agreed that restaurant services of hotels in João Pessoa are market differentials. $\mathrm{H} 2$ said, "Yes, because people are becoming more and more attracted to the convenience of finding good restaurants in hotels, and being able to enjoy such well-designed menus as well-rated restaurants in the city, and it certainly contributes financially." In this respect, it is necessary to emphasize that the consumer is looking to fill a gap, or supply a need, when enjoying a product or service (Kotler, 1998). Hotel restaurants should bear this in mind when developing strategies for attracting customers, since what is offered in terms of food services can constitute a competitive differential over other restaurants, whether based in other hotels or not.

Next, the interviewees were asked if the restaurant was a differential for attracting guests, and $75 \%$ stated that it is a differential because guests value comfort. $\mathrm{H} 1$ replied: "Yes, for the convenience of having meals at their disposal, snacks and appetizers without leaving the hotel." Only H3 replied that the restaurant itself was not quite a differential, but that the breakfast attracted guests.
When asked if the restaurant is a differential to attract visitors (residents and guests of other hotels), all of them agreed $(100 \%)$, stating that local people or guests of other hotels generally use the restaurant services. $\mathrm{H} 1$ said that the hotel attracted people from the locality, including for the offer of a range of services, besides food. He pointed out that: "(...) we even have the day use, where everyone can enjoy the pool, leisure area, including meals or not. $\mathrm{H} 2$ pointed out why the restaurant is a differential in this regard while emphasizing the following: "because the hotel is a reference in the city for its sustainable concept, its excellent location, and its pleasant and welcoming environment with the eco-design concept, valuing works by local artists. The service also is one of our differentials, providing a differentiated welcome and a unique personalized experience." Thus, it was evidenced that the hotels had different mechanisms to attract customers to their restaurants. Despite the hotels' efforts to attract external customers, most of the public that used the restaurant service was guests.

The type of cuisine offered by the hotels is shown in the table below:

Table 2: Types of hotel cuisine

\begin{tabular}{c|c}
\hline Hotel & Types of cuisine \\
\hline $\mathrm{H} 1$ & Diversified \\
\hline $\mathrm{H} 2$ & Northeastern Region \\
\hline $\mathrm{H} 3$ & Mediterranean and Northeastern Region \\
\hline $\mathrm{H} 4$ & Brazilian \\
\hline $\mathrm{H} 5$ & $\begin{array}{c}\text { Northeastern Region and Mediterranean (Italian } \\
\text { and Portuguese) }\end{array}$ \\
\hline
\end{tabular}

Source: Research data (2020).

It was seen that all the hotels made use of Brazilian an$\mathrm{d} /$ or Northeastern regional cuisine. This demonstrated an appreciation of the food culture by most of the hotels interviewed. When asked about the type of cuisine offered by the hotel, $\mathrm{H} 2$ said: "The restaurant has dishes that are carefully prepared by the chef, extolling contemporary regional cuisine through the appreciation of regional elements; the menu was chosen with the appreciation of regional products in mind, aligned with the sustainable concept of the hotel, using fresh products harvested daily in our garden". As Schlüter (2003, p.11) explained, "traditional cuisine is being increasingly recognized as a valuable component of the intangible heritage of peoples. This is evidenced by Richards (1999), who states that regionalization can be used as a communication and marketing tool for tourism, and for those looking for local and regional authenticity, food can become a reason to visit a particular destination. As a result, he says, authenticity is seen 
as an important aspect of consumption in tourism, and in the search for local and regional authenticity, food can become a reason to visit a particular destination. Schlüter (2003) points out that gastronomy is a form of expression in which products or raw materials that are developed in the place where this society is inserted are used and valued.

The interviewees were then asked whether the restaurant management of the hotels was outsourced or owned. It was found that $100 \%$ of the interviewees managed their restaurants, and did not outsource. According to some authors, outsourcing some of the activities can countless benefits for companies, such as reducing costs and increasing profits, increasing the quality of products and services, and through good management, customer loyalty (Giosa, 1997; Akl, 2006; Haynes \& Ninemeier, 2005).

In the script there were four other questions related to outsourcing, however, since the hotels had their own form of management, there was no need to ask these questions. Had any of hotels outsourced their food services, they would have been asked: what motivated the hotel to make the decision to outsource; how was the outsourced company chosen; how does the hotel monitor the outsourced management and whether the company has any procedure for dealing with customer complaints.

In general, the results point to important strategies that can be adopted by hotel managers regarding food services, and can contribute to decision making. Hotels can reflect on these results, on the importance of not only offering these services, but also how they are offered, i,e, the mix of products offered, the differentials, the type of cuisine, etc. An important point to highlight is the catering service, which is not widely used by the hotels researched, but can be an important source of income. Another aspect that deserves consideration by the managers is outsourcing of food services.

The final issue relates to advertising the restaurants that operate in hotels, considering that their target public is not restricted to guests but include tourists, visitors from nearby cities, and local residents of the cities where the developments are installed.

\section{Final Considerations}

This research analyzes the importance of food services of hotels in the city of João Pessoa - Paraíba, seeking to determine whether the food services offered in these establishments are considered market differentials, in the $A \& B$ managers' view. For this purpose, interviews were conducted with five managers, who agreed to answer questions on the topics addressed.

Based on the analysis, it was concluded of the $A \& B$ managers interviewed, all considered the food services to be a market differential, and that through the dishes served, it is possible to attract different publics. It was also observed that the hotels use similar ways to increase their financial income through this sector. The results of using a restaurant environment in the hotel became evident in the financial income, or the profit margins they obtained.

Another point raised was the form of restaurant management, where all hotels had their own management. From the point-of-view of the literature used, outsourcing could bring several benefits in relation to costs, profit and customer loyalty. All the managers stated that they believe in the importance of the restaurant services in the city of João Pessoa as a market differential, and that they are important to attract clients, residents and guests from other hotels, concluding that the main public of these restaurants was the hotel guests themselves.

Another aspect is that there is a valorization of the food culture by most of the hotel $A \& B$ managers interviewed, emphasizing that most hotels have regional and Brazilian cuisine, using local products. This factor leads to an increased search for environments that demonstrate authenticity and regionalism in the products and services offered, leading hotels to optimize their sources of income. The main finding of this research, based on the data analysis, confirms the hypothesis that the food services of the means of lodging in the capital of Paraiba state may constitute an effective market differential.

The study, although restricted to the city of João Pessoa-PB, can be fully replicated in other cities. The results may help hotel managers analyze their decisions regarding the management of food services in hotels, considering the importance of these services, consumer expectations, profit margins, and even rethinking the outsourcing of these services or other ways to increase their profitability.

As a suggestion for future work, we recommend expanding the research universe, to include more hotels and with different types of management for the purposes of comparing the financial results, in order to obtain greater generalization of results. Although this research involved few participants, the results represent a relevant contribution, as they illustrate the views of $A \& B$ hotel managers, as essential elements of the management of services offered in this tourism chain.

\section{REFERENCES}

Akl, K. V. (2006). Terceirização de serviços. Monografia (Especialização) - Curso de Direito, Centro Universitário das Faculdades Metropolitanas Unidas. São Paulo. Acesso em 08 de 03 de 2020, disponível em http://arquivo.fmu.br/prodisc/direito/ kvba.pdf 
Andrade, J. V. (1995). Turismo: fundamentos e dimensões. São Paulo: Ática.

Beni, M. C. (2000). Análise estrutural do turismo. São Paulo: SENAC.

Boyne, S., Williams, F., \& Hall, D. R. (2002). On the trail of regional success: Tourism food production and the Isle of Arran Taste Trail. In: G. Richards \& A. M. Hjalager (Eds.), Tourism and Gastronomy, 91-114. Routledge, London.

Cacho, A. N. B., \& Azevedo, F. F. (2010). O turismo no contexto da sociedade informacional. Revista Brasileira de Pesquisa em Turismo, vol. 4, núm. 2, pp. 31-48 Associação Nacional de Pesquisa e Pós -Graduação em Turismo. São Paulo, Brasil. Disponível em: <https://www.redalyc.org/ pdf/5041/504152249003.pdf>. Acesso em: 07 de jan. de 2021.

Cândido, I., \& Viera, E. V. (2003). Gestão de hotéis: técnicas, operações e serviços. Caxias do Sul: UCS

Carvalho , L. C., \& Vasconcellos, M. (2006). Introdução à economia do turismo. São Paulo: Saraiva.

Castelli, G. (2006). Gestão Hoteleira. São Paulo: Saraiva.

Chon, K. S., \& Sparrowe, R. T. (2003). Hospitalidade: Conceitos e Aplicações. São Paulo: Pioneira Thomson Learning.

Costa, D. S. (2010). A gente não quer só comida: de Carême a Maslow, como o profissional de Relações Públicas pode contribuir com o Planejamento Estratégico de restaurantes. Trabalho de conclusão do Curso (Graduação em Comunicação Social - Habilitação em Relações Públicas, p. 38.

Finkelstein, J. (2005). Cozinha chique: o impacto da moda na alimentação. Em D. SLOAN, Gastronomia, restaurantes e comportamento do consumidor. Barueri: Manole.

Fonseca, J. J. (2002). Metodologia da pesquisa científica. Fortaleza: UEC

Gil, A. C. (2007). Como elaborar projetos de pesquisa. São Paulo: Atlas.

Gil, A. C. (2008). Métodos e técnicas de pesquisa social. São Paulo: Atlas.

Giosa, L. (1997). Terceirização: uma abordagem estratégica. São Paulo: Pioneira.

Godoi, C., \& Balsini, C. (2006). A pesquisa qualitativa nos estudos organizacionais brasileiros: uma análise bibliométrica. Em A. SILVA, Pesquisa qualitativa em estudos organizacionais. São Paulo: Saraiva.

Hall, C.M. \& Sharples, L. (2003). The consumption of experiences or the experiences of consumption? An introduction to the tourism of taste. C. Michael Hall, Liz Sharples, Richard Mitchell, Niki Macionis and Brock Cambourne (Ed.) Food Tourism: Around the World: Development, Management and Markets. Chapter 1, p.1-24, ButterworthHeinemann, Oxford.
Haynes , D. K. \& Ninemeier, J. D. (2005). Gestão de operações hoteleiras. São Paulo: Pearson Prentice Hall.

Kotler, P. (1998). Administração de marketing: análise, planejamento,implementação e controle. São Paulo: Atlas.

Lickorish, L. J., \& Jenkins, C. L. (2000). Introdução ao turismo. Rio de Janeiro: Campus.

Mak, A. H.; Lumbers, M.; Eves, A.; Chang, R. C. (2012) Factors Influencing Tourist Food Consumption International Journal of Hospitality Management 31: (3), 928-936

Mees, L. A. (2019). Do desejo de restauração à busca pela refeição rápida: práticas de alimentação e comensalidade, do surgimento do restaurante à modernidade. Em M. A. OLIVEIRA, E. VANZELLA \& A. BRAMBILLA, ALIMENTAÇÃO E CULTURA PROCESSOS SOCIAIS: sistemas culinários em contexto de ressignificacõ̃es, comensalidade, processos discursivos e religiosos. João Pessoa: Editora do CCTA.

Meler, M. and Cerovic', Z. (2003), "Food marketing in the function of tourist product development", British Food Journal, Vol. 105 No. 3, pp. 175-192.

Organização Mundial do Turismo. (2001). Introdução ao turismo. São Paulo: Roca.

Organização Mundial do Turismo (2012). Global Report on Food Tourism. UNWTO, Madrid.

Porto Editora. (2015). Dicionário de Língua Portuguesa . Portugal.

Ramos, D. M., \& Costa, C. M. (2017). Turismo: tendências de evolucão. PRACS: Revista Eletrônica de Humanidades do Curso de Ciências Sociais da UNIFAP Disponível em: <https://periodicos.unifap.br/ index.php/pracs> ISSN 1984-4352 Macapá, v. 10 n. 1, p. 21-33. Acesso em 07 de jan. de 2021

Rejowskl, M. (2005). Turismo no percurso do tempo. (Vol. 2). São Paulo: Aleph.

Richards, G. (1999). Cultural tourism in Europe. Wallingford: CAB International.

Schlüter, R. G. (2003). Turismo e Gastronomia. São Paulo: Aleph

Sena, L. L. (2008). Como Administrar Hotéis. Viçosa: CPT.

Silva, C.G. (2006). A importância dos serviços de alimentação junto aos meios de hospedagem gaúchos - estudo de caso de hotéis na cidade de Porto Alegre. Dissertação apresentada ao Programa de Mestrado em Turismo.

Torre, F. (2001). Administração hoteleira, parte I: departamentos. São Paulo: Roca.

Vargas, M. C. (2009). Serviços especiais de alimentação na hotelaria de Luxo de porto alegre: um estudo de caso. Trabalho de conclusão de Curso (Graduação em Turismo) .

Walker, J. R. (2002). Introdução à hospitalidade. Barueri: Manole. 